\title{
Essential oil of Mitracarpus frigidus as a potent source of bioactive compounds
}

\author{
RODRIGO L. FABRI ${ }^{1}$, ELAINE S. COIMBRA ${ }^{2}$, ANA C. ALMEIDA ${ }^{2}$, EZEQUIAS P. SIQUEIRA ${ }^{3}$, \\ TÂNIA M.A. ALVES ${ }^{3}$, CARLOS L. ZANI ${ }^{3}$ and ELITA SCIO ${ }^{1}$ \\ ${ }^{1}$ Laboratório de Produtos Naturais Bioativos, Departamento de Bioquímica, Instituto de Ciências Biológicas, \\ Universidade Federal de Juiz de Fora, Rua José Lourenço Kelmer, s/n, São Pedro, 36036-900 Juiz de Fora, MG, Brasil \\ ${ }^{2}$ Departamento de Parasitologia, Microbiologia e Imunologia, Instituto de Ciências Biológicas, \\ Universidade Federal de Juiz de Fora, Rua José Lourenço Kelmer, s/n, São Pedro, 36036-900 Juiz de Fora, MG, Brasil \\ ${ }^{3}$ Centro de Pesquisa René Rachou - Fiocruz, Avenida Augusto Lima, 1715, \\ Barro Preto, 30190-002 Belo Horizonte, MG, Brasil
}

Manuscript received on March 28, 2011; accepted for publication on April 12, 2012

\begin{abstract}
In our previous work (Fabri et al. 2009), we showed that different extracts of Mitracarpus frigidus had significant antibacterial, antifungal and leishmanicidal activities. In order to increase our knowledge about this species, this work assesses the chemical composition and the in vitro biological activity of its essential oil. Thus, the essential oil obtained by hydrodistillation of the aerial parts of $M$. frigidus was analyzed by GC/MS. Among several compounds detected, 11 were identified, being linalool and eugenol acetate the major components. The essential oil exhibited a moderate antibacterial effect against Staphyloccocus aureus, Bacillus cereus, Pseudomonas aeruginosa and Enterobacter cloacae (MIC $250 \mu \mathrm{g} / \mathrm{mL}$ ). On the other hand, it showed a strong antifungal effect against Cryptoccocus neoformans (MIC $8 \mu \mathrm{g} / \mathrm{mL}$ ) and Candida albicans (MIC $63 \mu \mathrm{g} / \mathrm{mL}$ ). Expressive activity against L. major and L. amazonensis promastigote forms with $\mathrm{IC}_{50}$ values of 47.2 and $89.7 \mu \mathrm{g} / \mathrm{mL}$, respectively, were also observed. In addition, the antioxidant activity was investigated through DPPH radical-scavenging and showed a significative activity with $\mathrm{IC}_{50}$ of $38 \mu \mathrm{g} / \mathrm{mL}$. The cytotoxicity against Artemia salina was moderate with $\mathrm{LC}_{50}$ of $88 \mu \mathrm{g} / \mathrm{mL}$. The results presented here are the first report on the chemical composition and biological properties of M. frigidus essential oil.
\end{abstract}

Key words: Mitracarpus frigidus, essential oil, antimicrobial, antileishmanial, cytotoxicity.

\section{INTRODUCTION}

Some Mitracarpus species have ethnopharmacological importance as they are used in folk medicine for various purposes. For example, $M$. scaber is widely employed in traditional medicine in West Africa for headaches, toothache, amenorrhea, dyspepsia, hepatic diseases and leprosy. Among

Correspondence to: Elita Scio

E-mail: elita.scio@ufjf.edu.br those folkloric uses, the juice of the plant is applied topically for the treatment of skin diseases (Dalziel 1936, Kerharo and Adam 1974).

The potential antimicrobial activity of the aerial parts extracts of some Mitracarpus species against bacterial and mould strains, like Staphylococcus aureus, Bacillus cereus, Pseudomonas aeruginosa, Candida albicans and Cryptococcus neoformans were already reported (Irob and Daramola 1993, 
1994, Sanago et al. 1996). Also, in our previous work, we showed that $M$. frigidus extracts had a significant antibacterial, antifungal and leishmanicidal activities (Fabri et al. 2009). So, in order to increase our knowledge about $M$. frigidus, this work deals with the chemical composition and the in vitro activity against Gram-positive and Gram-negative bacteria and yeasts strains, promastigote forms of Leishmania species and cytotoxicity against Artemia salina of the essential oil of this specie. Its in vitro antioxidant activity was also determined.

\section{MATERIALS AND METHODS}

\section{PlANT MATERIAL}

M. frigidus aerial parts were collected in Juiz de Fora, Minas Gerais, Brazil, in May, 2006. Dr. Tatiana Konno identified the plant. A voucher specimen (CESJ 46076) was deposited at the Herbarium Leopoldo Krieger of the Universidade Federal de Juiz de Fora.

HydRodistillation OF Volatile OiLs

Essential oil was obtained by means of hydrodistillation $(3 \mathrm{~h})$ of the dried plant material using a Clevenger type apparatus. Oil was dried and stored at $4{ }^{\circ} \mathrm{C}$ until tested and analyzed.

Collection of Volatiles by Solid Phase Micro-

EXTRATION (SPME)

Fifty microliters from the $20 \mathrm{mg} / \mathrm{mL}$ solutions were transferred to a $2 \mathrm{~mL}$ glass vial and the solvent was removed under vacuum $\left(\right.$ speedVac $^{\circledR}$, SC250 model, ThermoSavant, U.S.A) for $18 \mathrm{~h}$, $30^{\circ} \mathrm{C}$ and 10 millibar. The vial was closed with a cap sealed Teflon coated septum (Supelco, U.S.A) and placed in a heat block adjusted to $90^{\circ} \mathrm{C}$. A SPME fiber (PDMS/DVB ${ }^{\mathrm{TM}} 65 \mu \mathrm{m}$, SUPELCO, U.S.A) was inserted with a manual holder through the septum and left in the headspace for $30 \mathrm{~min}$. Immediately after that, the holder with the saturated fiber was analyzed by means of injection on gas chromatography (GC) injection port. Before use, the fiber was preconditioned at $230^{\circ} \mathrm{C}$ during 30 min in the GC injector port.

GAS CHROMATOGRAPHY/MASS SPECTROMETRY ANALYSIS

Gas Chromatography/Mass Spectrometry (GCMS) analyses were performed on a Shimadzu QP5050A (SHIMADZU, JP) instrument, equipped with a PTE ${ }^{\mathrm{TM}}-5$ column $(30 \mathrm{~m}, 0.25 \mathrm{~mm}, 0.25$ $\mu \mathrm{m}$, Supelco, USA), using helium as the carrier gas. The following conditions were employed for all analysis: helium at $22.3 \mathrm{~mL} / \mathrm{min}$; injector temperature maintained at $230^{\circ} \mathrm{C}$; the oven at $80^{\circ} \mathrm{C}$ during 3 minutes and then heated to $300^{\circ} \mathrm{C}$ at $7^{\circ} \mathrm{C} /$ min, holding for $5 \mathrm{~min}$ at $300^{\circ} \mathrm{C}$. The split valve was closed during the first minute of injection and then opened, with a 1:10 ratio. The mass detector was set to scan from 50 to $500 \mathrm{~m} / \mathrm{z}$, at a rate of 2 scans per second. Data acquisition and handling was done via CLASS 5000 Shimadzu software.

\section{ANALYSIS OF THE RAW DATA USING AMDIS SOFTWARE}

(Automated Mass Spectral DeCONVOLUTION AND IDENTIFICATION SYSTEM)

Raw data files were analyzed by Automated Mass Deconvolution and Identification System software (AMDIS), version 2.1, supplied by National Institute of Standards and Technology (NIST, USA). Retention Index (RI) in the range of 900 to 3,000 was generated from the analysis of a standard mixture containing hydrocarbons C9 to C30 (Fluka, U.S.A).Elucidation of the compounds was done by means of the NIST MS Search 2.0 Program (NIST/ EPA/NIH Mass Spectral Library, version 2002) and on the basis of comparison of retention indices determined according Van Den Dool and Kratz (1963) for each constituent, as well as, previously described by Adams (2007). 


\section{MicROBIAL STRAINS}

The sample was evaluated against a panel of microorganisms, including Staphylococcus aureus (ATCC 6538), Pseudomonas aeruginosa (ATCC 15442), Salmonella enterica sorovar Typhimurium (ATCC 13311), Shigella sonnei (ATCC 11060), Klebsiella pneumoniae (ATCC 13866), Escherichia coli (ATCC 10536), Bacillus cereus (ATCC 11778), Micrococcus luteus (ATCC 10054), Enterococcus faecalis (ATCC 51299), Enterobacter cloacae (ATCC 10699), Streptococcus pyogenes (ATCC 10096), Candida albicans (ATCC 18804) and Cryptococcus neoformans (ATCC 32608). Bacterial strains were cultured overnight at $37^{\circ} \mathrm{C}$ in Mueller Hinton agar (MHA). Yeasts were cultured for $48 \mathrm{~h}$ at $30^{\circ} \mathrm{C}$ in Sabouraud dextrose agar (SDA).

\section{Serial Dilution Assay for Determination of the}

MINIMAL INHIBITORY CONCENTRATION (MIC)

The minimal inhibitory concentration (MIC) was determined by using broth microdilution techniques for bacterial and yeasts (NCCLS 2002 Perez et al. 1990). MIC values were determined in RPMI 1640 (Sigma) buffered to a pH 7.0 with MOPS (Sigma) for yeasts and Mueller Hinton broth (MHB) for bacteria. Yeasts were cultured at $30^{\circ} \mathrm{C}$ for $48 \mathrm{~h}$ in SDA and bacteria were cultured overnight at $37^{\circ} \mathrm{C}$ for $24 \mathrm{~h}$ in MHA. Sample stock solutions were two-fold diluted from 5,000 to 2.5 $\mu \mathrm{g} / \mathrm{mL}$ (final volume $=80 \mu \mathrm{L}$ ) and a final DMSO concentration $\leq 1 \%$. Then, $100 \mu \mathrm{L}$ of RPMI or MHB were added onto microplates. Finally, $20 \mu \mathrm{L}$ of $10^{6} \mathrm{CFU} / \mathrm{mL}$ (according to McFarland turbidity standards) of standardized yeasts and bacterial suspensions were inoculated onto microplates and the test was performed in a volume of 200 $\mu \mathrm{L}$. Plates were incubated at $30^{\circ} \mathrm{C}$ for $48 \mathrm{~h}$ for yeasts and $37^{\circ} \mathrm{C}$ for $24 \mathrm{~h}$ for bacteria. The same tests were performed simultaneously for growth control (RPMI + yeast and MHB + bacteria) and sterility control (RPMI or MHB + essential oil).
The test was performed in duplicate. The MIC values were calculated as the highest dilution showing complete inhibition of tested strain.

\section{DPPH RADICAL SCAVENGING ASSAY}

The free radical scavenging activity of sample solutions in methanol was determined based on their ability to react with stable 1,1-diphenyl-2picrylhydrazyl (DPPH) free radicals (Govidarajan et al. 2003). The essential oil at various concentrations ( 7.8 to $250 \mu \mathrm{g} / \mathrm{mL}$ ) was added to a $152 \mu \mathrm{M}$ solution of DPPH in methanol. After incubation at $37^{\circ} \mathrm{C}$ for $30 \mathrm{~min}$, the absorbance of each solution was determined at $517 \mathrm{~nm}$. The antioxidant activity of essential oil was expressed as $\mathrm{IC}_{50}$ (inhibitory concentration), which was defined as the concentration (in $\mu \mathrm{g} / \mathrm{mL}$ ) of sample required to inhibit the formation of DPPH radicals by $50 \%$. $\alpha$-Tocopherol and rutin were used as positive control.

\section{ANTILEISHMANIAL ASSAY}

Three species of Leishmania were used in this study: L. chagasi (MHOM/Br/74/PP75), L. amazonensis (MHOM/Br/75/Josefa) and L. major (MRHO/SU/59/P). Anti-leishmanial activity was determined by the colorimetric 3-(4,5-dimethylthiazol-2-yl)-2,5-diphenyltetrazolium bromide (MTT) method based on tetrazolium salt reduction by mitochondrial dehydrogenases (Braga et al. 2007). Briefly, promastigotes of $L$. amazonensis and L. major were cultured in Warren's medium (brain heart infusion plus hemin and folic acid) and promastigotes of L. chagasi were maintained in Medium 199, both supplemented with $10 \%$ fetal bovine serum at $24^{\circ} \mathrm{C}$. The screening was performed in 96well microtiter plates maintained at $24^{\circ} \mathrm{C}$. The essential oil solution in DMSO was added in a serial solution in the wells (11 to $108 \mu \mathrm{g} / \mathrm{mL}$ ). Then a parasite suspension from a logarithmic phase 
culture was suspended to yield 2 million cells $/ \mathrm{mL}$ (L. amazonensis or L. major) or 3 million cells/ $\mathrm{mL}$ (L. chagasi) after Neubauer chamber counting. Controls with DMSO and without plants samples were performed. All the tests were performed in triplicates. The viability of promastigotes was assayed after a three day incubation period with addition of MTT. The reaction was stopped with $\mathrm{HCl}$ in isopropyl alcohol and the optical densities were evaluated in a spectrophotometer at $570 \mathrm{~nm}$ (Multiskan MS microplate reader, LabSystems Oy, Helsink, Finland). The results were expressed as the concentrations inhibiting parasite growth by $50 \%\left(\mathrm{IC}_{50}\right)$ and the percentage of inhibition of parasite growth. Amphotericin B was used as the standard drug.

\section{CYTOTOXICITY ASSAY}

Brine shrimp lethality bioassay (Meyer et al. 1982) was carried out to investigate the cytotoxicity of the essential oil. Brine shrimp (Artemia salina Leach) eggs were hatched in a beaker filled with sea water under constant aeration. After $48 \mathrm{~h}$, the nauplii were collected by pipette and were counted macroscopically in the stem of the pipette against a lighted background. Solutions of the essential oil were made in seawater containing $1 \% \mathrm{DMSO}$, at varying concentrations (10 to $1,000 \mu \mathrm{g} / \mathrm{mL}$ ) and incubated in triplicate vials with 10 brine shrimp larvae. After $24 \mathrm{~h}$ of incubation, the nauplii were examined against a lighted background, with a magnifying glass and the number of survivors in each vial were counted and noted. Both positive (thymol) and negative (sea water containing $1 \%$ DMSO) control assays were carried out in order to verify the susceptibility of A. salina under assay conditions employed.

\section{STATISTICAL ANALYSIS}

The $\mathrm{IC}_{50}$ for antioxidant activity was calculated by Grafit 5. The $\mathrm{IC}_{50}$ for leishmanicidal activity and cytotoxicity were calculated by Probit analysis.
Both were expressed as mean \pm standard error (SE). The inhibition percentages for leishmanicidal activity were analyzed by Graph Pad Prisma 4 . Statistical differences between the treatments and the control were evaluated by ANOVA test.

\section{RESULTS}

CHEMICAL COMPOSITION

Water-distillation of the dried aerial parts of $M$. frigidus yielded $0.01 \%(\mathrm{v} / \mathrm{w})$ of an orange oil. Chemical analysis of the oil's components resulted in the identification of 12 known components (Table I). Linalool (29.29\%) and eugenol acetate (15.85\%) were the major constituents of the essential oil, followed by 5-hydroxy-isobornyl isobutyrate (8.41\%), 5-methyl-1-undecene (7.69\%) and methyl salicylate $(6.55 \%)$.

\section{ANTIMICROBIAL ACTIVITY}

The essential oil of M. frigidus exhibited a moderate antibacterial effect against Staphyloccocus aureus, Bacillus cereus, Pseudomonas aeruginosa and Enterobacter cloacae (MIC $250 \mu \mathrm{g} / \mathrm{mL}$ ) (Table II). On the other hand, the oil showed a strong antifungal effect against Cryptoccocus neoformans (MIC 8 $\mu \mathrm{g} / \mathrm{mL}$ ) and Candida albicans (MIC $63 \mu \mathrm{g} / \mathrm{mL}$ ). It was considered that if the extracts displayed a MIC less than $100 \mu \mathrm{g} / \mathrm{mL}$, the antimicrobial activity was good; from 100 to $500 \mu \mathrm{g} / \mathrm{mL}$, moderate; from 500 to $1,000 \mu \mathrm{g} / \mathrm{mL}$, weak; over $1,000 \mu \mathrm{g} / \mathrm{mL}$ the extract was considered inactive (Holetz et al. 2002).

\section{ANTILEISHMANIAL ACTIVITY}

The effect of the essential oil of $M$. frigidus on the viability of promastigotes of $L$. major, $L$. amazonensis and L. chagasi was tested. The essential oil showed expressive activity against $L$. major and L. amazonensis promastigote forms with $\mathrm{IC}_{50}$ values of $47.2 \pm 4.0$ and $89.7 \pm 8.6 \mu \mathrm{g} / \mathrm{mL}$, respectively. Those forms were susceptible to the essential oil 
TABLE I

Chemical constituents, retention index and relative concentration of compounds of essential oil of Mitracarpus frigidus analyzed by GC-MS.

\begin{tabular}{lccccc}
\hline No & Compound & $\begin{array}{c}\text { Retention time } \\
(\mathbf{m i n})\end{array}$ & \% relative & $\begin{array}{c}\text { Retention } \\
\text { index }\end{array}$ & $\begin{array}{c}\text { Molecular } \\
\text { Mass }\end{array}$ \\
\hline 1 & 7-Octen-4-ol & 4.07 & 5.03 & 850.8 & 128 \\
2 & 5-Hydroxy-isobornyl isobutyrate & 5.0 & 8.41 & 1033.9 & 276 \\
3 & 5-methyl-1-Undecene & 6.39 & 7.69 & 1092.1 & 168 \\
4 & Linalool & 6.53 & 29.29 & 1098.9 & 154 \\
5 & -Phenylethyl alcohol & 6.85 & 3.79 & 1113.5 & 122 \\
6 & Cucumber aldehyde & 7.63 & 3.55 & 1149.4 & 138 \\
7 & trans-2-Nonenal & 7.77 & 4.83 & 1155.6 & 140 \\
8 & Methyl salicylate & 8.61 & 6.55 & 1194.3 & 152 \\
9 & 8-Isobutyryloxy-isobornyl isobutyrate & 9.38 & 4.66 & 1230.1 & 281 \\
10 & Not known & 9.87 & 5.99 & 1253.0 & 341 \\
11 & Eugenol acetate & 12.04 & 15.85 & 1357.6 & 206 \\
12 & Damascenone & 12.58 & 4.36 & 1384.7 & 190 \\
\hline
\end{tabular}

TABLE II

Antimicrobial activity of Mitracarpus frigidus essential oil.

\begin{tabular}{ccc}
\hline Test microorganisms & $\begin{array}{c}\text { MIC } \\
(\mu \mathbf{g} / \mathbf{m L})^{\mathbf{a})}\end{array}$ & $\mathbf{S}^{\mathbf{b})}$ \\
\hline Bacteria & & \\
Staphylococcus aureus & 250 & $62.5^{\mathrm{c})}$ \\
Escherichia coli & 500 & $15.6^{\mathrm{c})}$ \\
Salmonella typhimurium & 1,000 & $1.0^{\mathrm{c})}$ \\
Shigella sonnei & 1,000 & $1.0^{\mathrm{c})}$ \\
Klebsiella pneumoniae & 500 & $1.0^{\mathrm{c})}$ \\
Bacillus cereus & 250 & $3.9^{\mathrm{c})}$ \\
Pseudomonas aeruginosa & 250 & $15.6^{\mathrm{c})}$ \\
Enterobacter cloacae & 250 & $31.3^{\mathrm{c})}$ \\
Enterococcus faecalis & 1,000 & $31.3^{\mathrm{c})}$ \\
Streptococcus pyogenes & 500 & $15.6^{\mathrm{c})}$ \\
$\quad$ Yeasts & & \\
Candida albicans & 63 & $0.08^{\mathrm{d})}$ \\
Cryptococcus neoformans & 8 & $0.04^{\mathrm{d})}$ \\
\hline
\end{tabular}

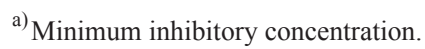

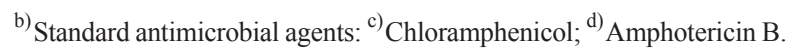

at $108 \mu \mathrm{g} / \mathrm{mL}$ with $97 \%$ and $86 \%$ cell inhibition, respectively (Figure 1). Interestingly, L. major presented the greatest dose-dependent relationship. On L. chagasi, the percentage of inhibition did not varied significantly between the concentrations used. The percentage of inhibition presented by reference drug Amphotericin B at $10 \mu \mathrm{g} / \mathrm{mL}$ was 60 $\%, 90 \%$ and $86 \%$ for L. major, L. amazonensis and L. chagasi promastigotes, respectively.

\section{ANTIOXIDANT ACTIVITY}

The antioxidant activity of the essential oil of $M$. frigidus was investigated through DDPH radicalscavenging and showed a moderate activity with $\mathrm{IC}_{50}$ of $38 \pm 8 \mu \mathrm{g} / \mathrm{mL}$. The reference controls $\alpha$-tocopherol and rutin presented $\mathrm{IC}_{50}$ of $0.2 \pm 0.1$ and $3 \pm 1.8 \mu \mathrm{g} / \mathrm{mL}$, respectively.

\section{CYTOTOXICITY}

The cytotoxicity against Artemia salina was moderate with $\mathrm{LC}_{50} 88 \pm 10 \mu \mathrm{g} / \mathrm{mL}$. The reference control thymol showed $\mathrm{LC}_{50}$ of $1.4 \pm 0.7 \mu \mathrm{g} / \mathrm{mL}$.

\section{DISCUSSION}

The essential oil exhibited a moderate antibacterial and a strong antifungal effect against Cryptoccocus neoformans and Candida albicans. Also, it showed expressive activity against Leishmania major and L. amazonensis promastigote forms. 


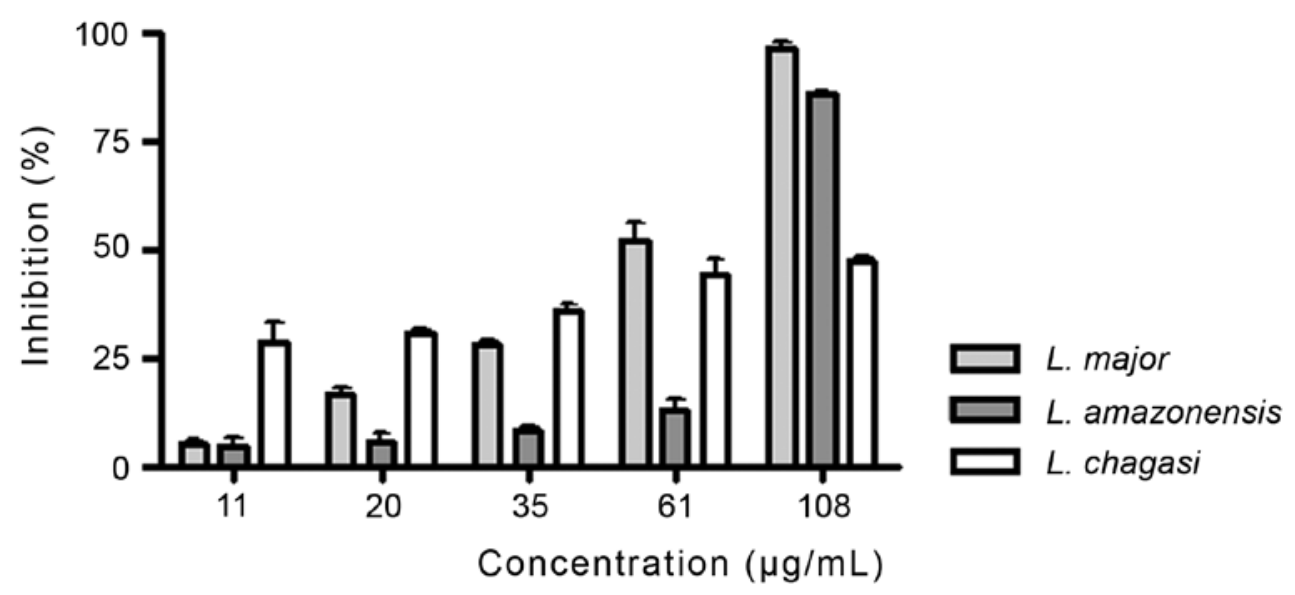

Figure 1 - Effect of the essential oil from M. frigidus on growth of L. major, L. amazonensis and L. chagasi promastigote forms. Parasites were treated with 11 to $108 \mu \mathrm{g} / \mathrm{mL}$ essential oil. Each bar represents the mean \pm standard deviation of three different experiments.

Linalool and eugenol acetate were the major constituents of the essential oil. Linalool is a monoterpene commonly found in the essential oils of some aromatic plants. It is also obtained as a by-product in the industrial synthesis of vitamin E (Ohashi et al. 1997). Its biological activity, including antioxidant, antimicrobial, antiinflammatory, anesthetic and antitumor was already reported (Ghelardini et al. 1999, Mazzanti et al. 1998, Letizia et al. 2003, Dadasoglu et al. 2011). Also, the ability to inhibit the development of the mosquito larvae of Aedes aegypt has been attributed to linalool (Gottlieb et al. 1981). Eugenol acetate is a derivative of eugenol, which is employed as antimicrobial, anti-inflammatory, anesthetic, antiseptic, antioxidant, repellent agent, and in cosmetics and condiments (Lahlou 2004).

Cryptoccocus neoformans and Candida albicans are opportunistic pathogens commonly associated with disease in immunocompromised hosts. C. neoformans causes systemic disease, and cryptococcal infection is usually acquired by inhalation of fungal cells and can be limited to the lung or disseminate to the central nervous system, causing meningoencephalitis (Rodrigues et al. 1999). C. albicans can cause local and systemic infection and it is found normally in the buccal and vaginal regions (Zhang and Lewis 1997). The lipophylicity of the essential oil constituents could explain their antimicrobial activity, a characteristic that allows the partition of these compounds in lipids of cell membrane and mitochondria, increasing their permeability and leading to leakage of cellular contents (Cowan 1999). According to other authors, essential oil constituents can also act on cellular proteins located in cytoplasm membranes, including the ATPases, by their accumulation in the lipid double layer and the consequent destruction of lipid-protein interaction (Ultee et al. 2002, Burt 2004). Alternatively, a direct interaction of lipophylic compounds may occur with the hydrophobic portions of proteins (Juven et al. 1994, Sikkema et al. 1995). However, due to the large number of different chemical groups present in essential oils, it is likely that its antimicrobial activity is not related to a specific mechanism of action (Carson et al. 2002, Kalemba and Kunicka 2003, Skadamis and Nychas 2001).

Leishmaniasis is a chronic disease that can assume different fatal clinical forms ranging from selfhealing cutaneous to progressive mucocutaneous infection, and potentially visceral leishmaniasis (Tripathi et al. 2007). According to the World 
Health Organization (2004), leishmaniasis currently threatens 350 million people around the world and it is estimated that 2 million new cases occur each year. A common feature of volatiles compounds is their hydrophobic nature. Several studies addressing the action mode of such compounds usually point to cell membranes as the primary target as the essential oils, in general, have a passive entry through the membrane, leading to an increase of membrane permeability (Bakkali et al. 2008).

Antioxidant activity possibly proceeds from the presence of phenolic compounds such as methyl salicylate in the oil. The brine shrimp lethality assay is based on the ability to kill laboratorycultured Artemia salina nauplii brine shrimp and it is considered to be one of the most useful tool for the preliminary assessment of general toxicity (Maclaughlin 1991). $\mathrm{LC}_{50}$ values $<250 \mu \mathrm{g} / \mathrm{mL}$ are considered significant for plant samples and had the potential for futher investigation (Rieser et al. 1996).

The results presented here are the first report on the chemical composition and biological properties of the Mitracarpus essential oil.

\section{ACKNOWLEDGMENTS}

The authors are grateful to Dr. Tatiana Konno for the botanical identification of species and Fundação de Amparo à Pesquisa do Estado de Minas Gerais (FAPEMIG) (CEX APQ 1128/05 and CEX APQ2874-5.02/07)/Brazil for financial support.

\section{RESUMO}

Em nosso trabalho anterior (Fabri et al. 2009), mostramos que diferentes extratos de Mitracarpus frigidus apresentaram atividades antibacteriana, antifúngica e leishmanicida significativas. Com o objetivo de aprofundar o conhecimento sobre essa espécie, esse trabalho objetiva identificar os constituintes químicos e avaliar as atividades biológicas in vitro de seu óleo essencial. Dessa forma, o óleo essencial das partes aéreas de M.frigidus foi obtido por hidrodestilação e analisado por CG/EM. Entre os compostos detectados, 11 foram identificados, sendo linalol e o acetato de eugenol os componentes majoritários. O óleo essencial de $M$. frigidus exibiu moderada atividade antibacteriana contra Staphyloccocus aureus, Bacillus cereus, Pseudomonas aeruginosa e Enterobacter cloacae (CIM $250 \mu \mathrm{g} / \mathrm{mL}$ ). Por outro lado, apresentou forte efeito antifúngico contra Cryptoccocus neoformans (CIM $8 \mu \mathrm{g} / \mathrm{mL}$ ) e Candida albicans (CIM $63 \mu \mathrm{g} / \mathrm{mL}$ ). Expressiva atividade contra as formas promastigostas de Leishmania major e Leishmania amazonensis com valores $\mathrm{CI}_{50}$ de 47,2 e $89,7 \mu \mathrm{g} / \mathrm{mL}$, respectivamente, também foi observada. Além disso, a atividade antioxidante foi investigada através do ensaio com o radical DPPH e este apresentou uma significativa atividade com $\mathrm{CI}_{50}$ de $38 \mu \mathrm{g} / \mathrm{mL}$. A citotoxidade contra Artemia salina foi moderada com $\mathrm{CL}_{50}$ de $88 \mu \mathrm{g} / \mathrm{mL}$. Os resultados aqui apresentados são o primeiro relato sobre a composição química e propriedades biológicas do óleo essencial M. frigidus.

Palavras-chave: Mitracarpus frigidus, óleo essencial, antimicrobiano, leishmanicida, citotoxidade.

\section{REFERENCES}

ADAMS RP. 2007. Identification of essential oil components by gas chromatograpy/ quadrupopole mass spectroscopy. Allured Publishing Corporation, Carol Stream, IL, USA, $804 \mathrm{p}$.

Bakkali F, AVerbeck S, AVERbeck D AND IDAOMAR M. 2008. Biological effects of essential oils - a review. Food Chem Toxicol 46: 446-475.

Braga FG, Bouzada MLM, FABri RL, Matos MO, MoreIrA FO, ScIO E AND COIMBRA ES. 2007. Antileishmanial and antifungal activity of plants used in traditional medicine in Brazil. J Ethnopharmacol 111: 396-402.

BURT S. 2004. Essential oils: their antibacterial properties and potential applications in foods - a review. Int J Food Microbiol 94: 223-253.

CARson CF, MeE BJ AND RILley TV. 2002. Mechanism of action of Melaleuca alternifolia (tea tree) oil on Staphylococcus aureus determined by time-kill, lysis, leakage and salt tolerance assays and eletron microscopy. Antimicrob Agents Ch 46: 1914-1920.

COWAN MM. 1999. Plant products as antimicrobial agents. Clin Microbiol Rev 12: 546-582.

Dadasoglu F, Aydin T, Kotan R, CAKIR A, Ozer H, Kordali S, CAKMAKCI R, DikBas N AND Mete E. 2011. Antibacterial activities of extracts and essential oils of three origanum species against plant pathogenic bacteria and their potential use as seed disinfectants. J Plant Pathol 93: 271-282. 
DALZIEL JM. 1936. Useful plants of West Tropical Africa. London: Crown Agents for the Colonies, $612 \mathrm{p}$.

FABri RL, NoGueIRA MS, BRAGA FG, COIMBRA ES AND SCIO E. 2009. Mitracarpus frigidus aerial parts exhibited potent antimicrobial, antileishmaninal, and antioxidant effects. Bioresource Technol 100: 428-433.

Ghelardini C, Galeotti N, Salvatore G and Mazzanti G. 1999. Local anaesthetic activity of the essential oil of Lavandula angustifolia. Planta Med 65: 700-703.

Gottlieb OR, Koketsu M, Magalhães MT, Maia JGD, MENDES AI, DA SiLVA ML AND WILBERG VC. 1981. Óleos essenciais da Amazônia. VII. Acta Amazonica 11: 143148.

GOVIDARAJAN R, RASTOGI S, VIJAYAKUMAR M, SHIRWAIKAR A, RAWAT AKS, MEHROTRA S AND PUSHPANGADAN P. 2003. Studies on the antioxidant activities of Desmodium gangeticum. Biol Pharm Bull 26: 1424-1427.

Holetz FB, Pessin GL, SAnches NR, Cortez DAG, NAKAMURA CV AND FILHO BPD. 2002. Screening of some plants used in the Brazilian folk medicine for the treatment of infectious diseases. Mem Inst Oswaldo Cruz 97: 1027-1031.

IROB ON AND DARAMOLA SO. 1993. Antifungal activities of crude extracts of Mitracarpus villosus (Rubiaceae). J Ethnopharmacol 40: 137-140.

IROB ON AND DARAMOLA SO. 1994. Bactericidal properties of crude extracts of Mitracarpus villosus. JEthnopharmacol 42: 39-43.

JuVEN BJ, KanNer J, SChVED F AND WeisSlOWicZ H. 1994. Factors that interact with the antibacterial action of thyme essential oil and its active constituents. J Appl Bacteriol 76: 626-631.

KalembA D AND KunICKA A. 2003. Antibacterial and antifungal properties of essential oils. Curr Med Chem 10: 813-829.

Kerharo J AND AdAm JG. 1974. La Pharmacopée Sénegalaise Traditionnelle: Plantes Médicinales Et Toxiques. Paris: Vigot Frères.

LAHLOU M. 2004. Methods to study the phytochemistry and bioactivity of essential oils. Phytother Res 18: 435-444.

Letizia CS, COCChiara J, LALKo J AND API AM. 2003. Fragrance material review on linalool. Food Chem Toxicol 41: 943-964.

MACLAUGHLIN JL. 1991. Crown gall tumours on potato discs and brine shrimps lethalithy: two simple bioassays for higher plant screening and fractionation. In: Hostettmann K (Ed), METHODS IN BIOCHEMISTRY. ASSAYS FOR BIOACTIVITY. London: Academic Press, p.1-32.

Mazzanti G, Battinelli L and SAlvatore G. 1998. Antimicrobial properties of the linalool-rich essential oil of Hyssopus officinalis L. var. decumbens (Lamiaceae). Flavour Fragr J 13: 289-294.
MEYER BN, FERRIGNI NR, PUTNAM JE, JACOBSEN LB, NICHOLS DE AND MaClaughlin JL. 1982. Brine shrimp: A convenient general bioassay for active plant constituents. Planta Med 45: 31-34.

NCCLS - NATIONAL COMMITTEE FOR CLINICAL LABORATORY STANDARDS. 2002. Reference method for broth dilution antifungal susceptibility testing of yeasts. Approved standard M27-A2 - P. National Committee for Clinical Laboratory Standards. Wayne, PA.

OHAshi ST, Rosa LS, SANTANa JA AND GREEN CL. 1997. Brazilian rosewood oil: sustainable production and oil quality management. Perf Flav 22: 1-5.

Perez C, Pauli M and Bazerque P. 1990. An antibiotic assay by the well agar method. Acta Biol Med Exp 15: 113-115.

RIESER MJ, GU ZM, FrANG I, WOOD KV AND MACLAUGHLIN JL. 1996. Five novel mono-tetrahydrofuran ring acetogenins from seeds of Annona muricata. J Nat Prod 59: 100-129.

Rodrigues ML, Alviano CS AND Travassos LR. 1999. Pathogenicity of Cryptococcus neoformans: virulence factors and immunological mechanisms. Microbes Infect 4: 293-301.

Sanogo R, Germanò MP, de Pasquale R, Keita A And BISIGNANO G. 1996. Selective antimicrobial activities of Mitracarpus scaber Zucc against Candida and Staphylococcus sp. Phytomedicine 2: 265-268.

SIKKEMA J, DE BONT JAM AND POOLMAN B. 1995. Mechanisms of membrane toxicity of hydrocarbons. Microbiol Rev 59: 201-222.

SKANDAMIS PN AND NYCHAS GJE. 2001. Effect of oregano essential oil on microbiological and physico-chemical attributes of minced meat stored in air and modified atmospheres. J Appl Microbiol 91: 1011-1022.

TRIPATHI P, SINGH V AND NAIK S. 2007. Immune response to Leishmania: paradox rather than paradigm. FEMS Immunol Med Microbiol 51: 229-242.

Ultee A, BenniK MH And MoezelaAR R. 2002. The phenolic hydroxylgroup of carvacrol is essential for action against the food-bornepathogen Bacillus cereus. Appl Environ Microbiol 68: 1561-1568.

VAn Den Dool H AND Kratz DJ. 1963. A generalization of the retention index system including liner temperature programmed gas-liquid partition chromatography. J Chromatograph 11: 463-467.

WHO - World Health ORganization. 2004. Report of the Scientific Working Group meeting on leishmaniasis.

ZHANG Y AND LEWIS K. 1997. Fabatins: new antimicrobial plant peptides. FEMS Microbiol Lett 149: 59-64. 